\section{The pros and cons of freedom of access to human genome data}

\section{Paris}

WHAT kinds of computer programs are needed to help scientists construct a complete sequence of the 3,000 million nucleotide base pairs making up the human genome? How can the results be shared by the entire scientific community without being impeded by "commercial, political or prestigious interests"? According to the Committee on Data for Science and Technology (CODATA) which organized a two-day meeting of world experts in Paris last week, these questions "have not been sufficiently explored". But, although goodwill was abundant, the meeting also uncovered

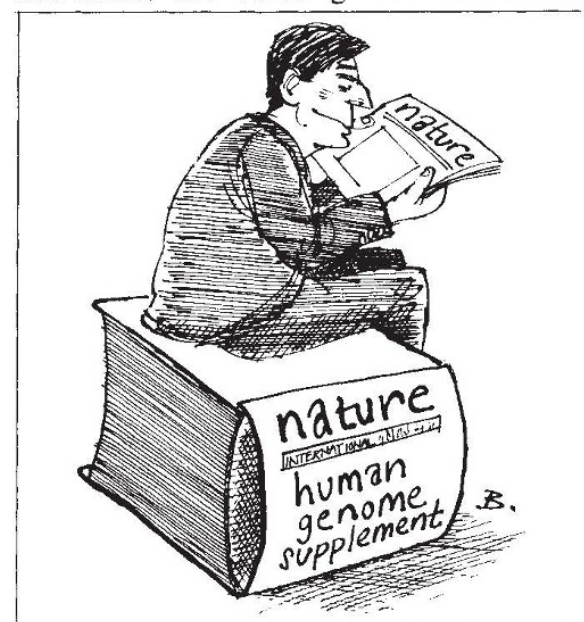

some worries, not least the power of the media in helping or hindering governments' interest in financing human genome research.

Data-processing remains essentially a practical matter and software houses are already creating 'user-friendly' programming environments for molecular biologists. But the question of what to do with the data is less evident. "As sequences get longer", says Professor George Bell of the biophysics and theoretical biology laboratory at Los Alamos, "publication in science journals will become impractical. Nobody will read them. In a couple of years, sequences will be published only in databanks." This is why access to databanks, such as those at Los Alamos and the European Molecular Biology Laboratory, should be open to scientists everywhere - one of the meeting's resolutions.

This spirit of scientific glasnost also underlies the multilateral 'gentlemen's agreement' to share results, to avoid duplication and to outlaw patent applications within the human domain. But if, as Charles de Lisi, former head of genome research at the US Department of Energy, says, "private enterprise cannot do the research", governments are aware that "transfer to the private sector will be rapid". Although the short-term rewards of human genome research will remain in the science domain - fast, low-cost automated sequencing, the availability of probes to hunt genes - the potential longterm commercial spin-off for pharmaceutical companies is incalculable.

When Boja Keil of the Pasteur Institute says that "the obstacles to progress are time and money", it is, for the moment, mostly US time and money. Japan, one of the countries best-placed to invest in human genome research, has so far only expressed interest. What is worrying some US experts is the threat of corporate takeover of US companies by wealthy Japanese banks, once the research has borne commercial fruit - a hint that political interests do not easily go away.

In Europe, politically active ecologists ('Greens') are perceived as partly responsible for the reluctance of governments to join the quest - particularly in West Germany. Aware of the potential power of the media to influence public opinion, for better or for worse, delegates at the Paris meeting resolved to seek to avoid distortion of scientific publications through popularization by overseeing journalists' interpretations.

The meeting also tackled ethical questions. Medical diagnosis - and possible treatment - of the 4,000 known single-

\section{London}

SiXTEEN officials of the Soviet Academy of Sciences have resigned in advance of the expiry of their term of office in 1991. They include six academic secretaries of departments of the Academy and 10 members of its ruling presidium. The resignations were tiya as an example of Mr Gorbachev's policy of "rejuvenation of cadres", that is, of the retirement of holders of administrative offices to make way for younger people.

Just when the retirement took place is not clear. Izvestiya reported it on 10 June, with a note that elections to fill the vacant offices would take place before 20 June. In fact, said Izvestiya, one such election - for the secretaryship of the Department of General and Technical Chemistry - had already taken place.

The head of the Academy's personnel department told Izvestiya that the resignation of so many high-ranking officials, although unprecedented, was simply part of the normal process of "changing the generations".

Nevertheless, it is clear that many hailed by the government newspaper Izves-

gene hereditary illnesses remains the most publicly acceptable motive for the research. Without the prospect of therapy however, screening is not always welcomed by potential sufferers. "But", says Bell, "if you don't know the cause you can't treat the illness."

While human genome research remains "far less expensive than moon-shot" and with more tangible short-term rewards, Bell emphasized that the complete sequencing of a human genome is only the beginning, not the end of the search. "We say 'the' human genome, but there are perhaps as many as 10 million differences between the genomes of two parents. We don't think these are all linked to individual genes, but we do not know."

Peter Coles

- A BILL establishing an inter-agency panel to coordinate US federal research efforts on the human genome project last week passed the Senate by an 88 to 1 margin. The Biotechnology Competitiveness Act also creates a national biotechnology policy board and advisory panel, a national centre for biotechnology information and an agricultural biotechnology panel. The act also establishes a biomedical ethics board, to review moral and ethical questions related to genome research.

The bill now goes to the House of Representatives, for hearings before three committees. Although the coming election has shortened the legislative calendar, the House may still act on the bill. Its chief Senate sponsor, Lawton Chiles (Democrat, Florida), retires this year, and has made the act a priority. J.P.

\title{
Early retirements in Academy's perestroika
}

members of the Academy are opposed to Mr Gorbachev's "rejuvenation" policy. Last autumn, when the first round of elections came due for vacancies created by the compulsory retirement of superannuated academicians, a significant number of the candidates proposed turned out to be over the new age-limit of 60 . And, as Izvestiya noted, the Academy still has 20 directors of institutes and 160 heads of divisions who are well past retirement age.

Superannuated officials who retire from office can still serve as "advisers" to the presidium, and many scientists who have retired in this manner have expressed their satisfaction at being relieved of tedious administrative duties. But not all, it seems, are willing to quit. The 16 eminent persons (including a former president of the Academy, Dr Anatolii Aleksandrov) who have retired en masse have, said Izvestiya, received official commendations for their "outstanding services to science and the organization of science". The tone of the Izvestiya report suggests that their good example in retiring is not the least of these "services".
Vera Rich 